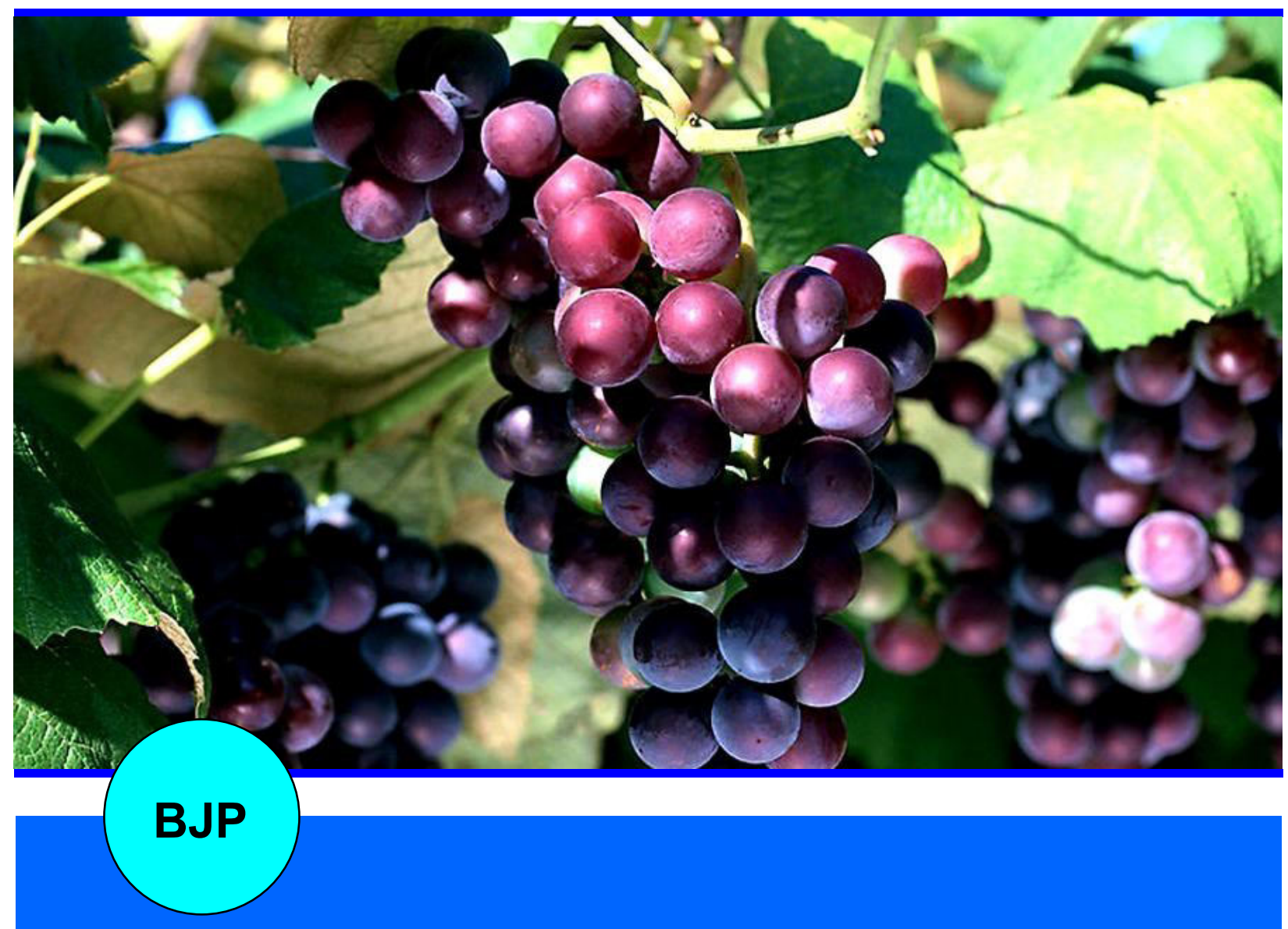

Bangladesh Journal of Pharmacology

Research Article

Vitis vinifera juice ameliorates depression-like behavior in mice by modulating biogenic amine neurotransmitters 


\title{
Vitis vinifera juice ameliorates depression-like behavior in mice by modulating biogenic amine neurotransmitters
}

\author{
Muhammad Aslam and Nuzhat Sultana
}

Department of Pharmacology, Faculty of Pharmacy, University of Karachi, Karachi 75 270, Pakistan.

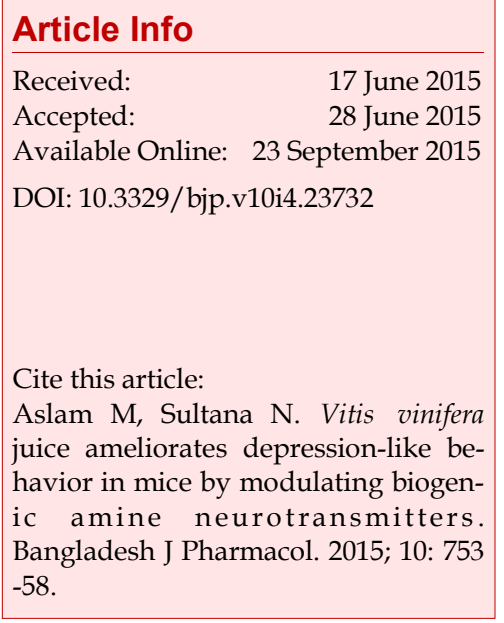

\begin{abstract}
The advantageous effects of Vitis vinifera juice on depressive model mice were examined utilizing a blend of behavioral evaluations and biogenic amine neurotransmitter estimations. During the behavioral evaluations, immobility time on the forced swimming test and tail suspension test were measured in unstressed and immobilization-induced stressed mice. $V$. vinifera juice $(4 \mathrm{~mL} /$ $\mathrm{kg}$ and $8 \mathrm{~mL} / \mathrm{kg}$ ) and fluoxetine $(20 \mathrm{mg} / \mathrm{kg})$ produced a significant decrease in immobility time of both unstressed and stressed mice when compared with their respective saline-treated control groups in both paradigms. Neurotransmitters were measured using high-performance liquid chromatography with electrochemical detector. $V$. vinifera juice raised the levels of both serotonin $(\mathrm{p}<0.001)$ and noradrenalin $(\mathrm{p}<0.001)$ in brain tissue. These outcomes give significant mechanistic insights into the protective effect of $V$. vinifera juice against depressive disorders. Our results showed that $V$. vinifera juice could relieve depressive manifestations in the rodent model of depression.
\end{abstract}

\section{Introduction}

Depression is a very incapacitating and broadly disseminated disease in the all-inclusive community. The World Health Organization has declared the depression as the most difficult illness of the society (Dang et al., 2009). Depressed mood, sentiments of blame or low self -esteem, loss of interest or delight, low vitality, poor concentration and disturbed sleep or appetite are the major signs and symptoms of the affective disorder (Yi et al., 2011). One of the most important hypotheses regarding the pathogenesis of depression is the monoamine hypothesis which recommends that there is a defect in monoaminergic pathways and the reduction in serotonin, norepinephrine and dopamine levels (Chuang et al., 2011). In current times, a number of antidepressant drugs are utilized as a part of clinical work, including selective serotonin reuptake inhibitors, tricyclic antidepressants, specific serotonin-norepinephrine reuptake inhibitors and selective reversible inhibitors of monoamine oxidase A (Fava, 2003). Nonetheless, these medications can cause numerous adverse drug reactions. Hence, substantial endeavors are made to discover the better medications for the therapeutic use to manage depression and other related disorders (Freitas et al., 2010).

Herbal medications are the antiquated type of health care known to people. These drugs are asserted to be more secure ones on account of the way that they have shown very few adverse effects in relation to new synthetic medications. Vitis vinifera Linn (grapes) family Vitaceae is a mystifying herb containing different element phytochemicals of pharmacological imperativeness. The oldest records of the consumption of grape products by people go back to 3500-2900 BC (Bowers, 1999). Among the Vitis species, V. vinifera is the most cultivated fruit crop around the world because of its use in wine production (Ali et al., 2009). Research studies show that it possesses cardioprotective activity (Frankel, 1993), antiulcer activity (Saito et al., 1998), antiallergic activity (Cheong et al., 1999) and anti-infla- 
mmatory activity (Xia et al., 2010).

$V$. vinifera is a very rich source of flavonoids and stillbenoids (Ali et al., 2009). Flavonoids are famous for possessing antidepressant activity (Zheng et al., 2013). To the best of our knowledge, there has been no investigative study to assess the antidepressant potential of $V$. vinifera. In view of the idea that flavonoids present in $V$. vinifera could be useful in depression, we evaluated antidepressant-like activity of $V$. vinifera juice using forced swimming test and tail suspension test in mice.

\section{Materials and Methods}

\section{Collection of plant material}

Fresh fruits of $V$. vinifera, White Kishmish variety, were purchased from local markets, Karachi, Pakistan. A pharmacognosist of the Department of Pharmacognosy, Ziauddin University, Pakistan, authenticated the sample.

\section{Preparation of juice}

$V$. vinifera fruits were squeezed by hand in a muslin cloth to yield fresh juice. Fresh fruit was used every day to obtain the juice. The yield was approximately 80-100 $\mathrm{mL} / 100 \mathrm{~g}$.

\section{Selection of animals}

A total number of 160 healthy Swiss male albino mice weighing between 20-25 g were procured from the animal house of University of Karachi, Pakistan.

\section{Division of animals into different groups}

The mice were kept ten per cage in polypropylene cages with a layer of sawdust litter under controlled conditions at room temperature $25-30^{\circ} \mathrm{C}$, relative humidity of $45-55 \%$ and 12/12 hours light-dark cycle. The mice were given standard pellets and water ad libitum. The pellets and water were withdrawn six hours before the administrations and during the experiments. The mice were divided into following 16 groups of 10 each:

\section{Groups for forced swimming test (unstressed mice)}

Group 1: Normal control; given normal saline $8 \mathrm{~mL} / \mathrm{kg}$, p.o.; Group 2: Treated group; given $V$. vinifera juice 4 $\mathrm{mL} / \mathrm{kg}$, p.o.; Group 3: Treated group; given $V$. vinifera juice $8 \mathrm{~mL} / \mathrm{kg}$, p.o.; Group 4: Standard drug group; given fluoxetine $20 \mathrm{mg} / \mathrm{kg}$, p.o.

\section{Groups for forced swimming test (stressed mice)}

Group 5: Control; given normal saline $8 \mathrm{~mL} / \mathrm{kg}$, p.o. and stressed by immobilization; Group 6: Treated group; given $V$. vinifera juice $4 \mathrm{~mL} / \mathrm{kg}$, p.o.; Group 7: Treated group; given $V$. vinifera juice $8 \mathrm{~mL} / \mathrm{kg}$, p.o.; Group 8: Standard drug group; given fluoxetine $20 \mathrm{mg} /$ $\mathrm{kg}$, p.o.

Groups for tail suspension test (Unstressed and stressed mice)

Groups 9 to 16 were divided in a similar manner as that of forced swimming test, except the antidepressant activity was assessed using the tail suspension test.

\section{Groups for locomotor activity}

These were the same as groups 1 to 16, except the locomotor activity was measured using home cages.

\section{Dosing}

The dose of $V$. vinifera juice was calculated according to the body weight of the mice. The juice was administered in mice at two different doses, i.e., $4 \mathrm{~mL} / \mathrm{kg}$ and 8 $\mathrm{mL} / \mathrm{kg}$. The dosing of the juice was done once daily according to the body weight of the animals.

\section{Immobilization-induced stress in mice}

Stress was brought about in the mouse by immobilizing it for $150 \mathrm{~min}$. The mouse was put on its back and all its four appendages and trunk was taped on a wooden board (Sheikh et al., 2007). Mice exposed to immobilization, were known as stressed mice. Behavioral tests were performed in independent groups of unstressed and stressed mice. Drugs were administered $45 \mathrm{~min}$ before immobilization in case of stressed group. Behavioral testing was started $10 \mathrm{~min}$ after setting the animals free from immobilization (Dhingra and Chhillar, 2012).

\section{Assessment of antidepressant-like activity}

Antidepressant-like activity was assessed by using forced swimming test and tail suspension test. Forced swimming test and tail suspension test are two wellestablished behavioral despair paradigms for the screening of antidepressant drugs (Liao et al., 2013).

\section{Forced swimming test}

This test was performed as per method (Porsolt et al., 1978). Briefly, mouse was forced to swim individually for $6 \mathrm{~min}$, in an open cylindrical container (diameter 10 $\mathrm{cm}$, height $25 \mathrm{~cm}$ ), containing $15 \mathrm{~cm}$ of water at $25 \pm 1^{\circ}$ C. Interestingly, mice put in the container were at first exceptionally dynamic, overwhelmingly swimming in circles, attempting to climb the divider or jumping to the base. After the initial $2 \mathrm{~min}$, movement starts to die down and to be scattered with periods of immobility or floating of increasing length. The length of immobility time was physically recorded during the following 4 min of the aggregate $6 \mathrm{~min}$ testing period. Mice were thought to be immobile when they stopped struggling and stayed drifting in water. Reduction in the length of time of immobility during this test was considered as antidepressant activity (Liao et al., 2013).

\section{Tail suspension test}

Tail suspension test is frequently used behavioral paradigm for screening antidepressant-like activity in 
mice. The total period of immobility was measured as per method (Steru et al., 1985). Briefly, each mouse was suspended on the edge of a table; $50 \mathrm{~cm}$ over the floor by sticky tape placed more or less $1 \mathrm{~cm}$ from the tip of the tail. During the test, every mouse was both visually and acoustically confined from other mice. The aggregate time of immobility was recorded physically for 6 min. The animal was thought to be stationary when it didn't demonstrate any kind of body movement, hung inactively and totally unmoving. The test was performed in the calm space to stay away from disturbances to mice.

\section{Assessment of locomotor activity}

Home cage test

The locomotor activity was evaluated in a familiar environment by using a home cage. The apparatus utilized as a part of this study was comprised of transparent perspex $(26 \times 26 \times 26 \mathrm{~cm})$ with a sawdust covered floor. The test was performed in a quiet room under white light as described elsewhere (Ikram et al., 2011) $15 \mathrm{~min}$ before monitoring the activity animals were placed in the home cage for habituation. Number of crossings across the box and grooming behavior were observed for $10 \mathrm{~min}$.

\section{Neurotransmitter analyses}

At the end of the experiment, the mice were decapitated and then immediately brains were removed from cranial cavity (Tahira et al., 2006) and then fresh brains were immediately dipped in chilled $0.9 \% \mathrm{w} / \mathrm{v}$ saline and stored at $-76^{\circ} \mathrm{C}$ for the estimation of brain biogenic amines and their metabolites. The frozen brains were weighed. At room temperature, according to the weight of brain, samples were homogenized using extraction medium. The homogenate was allowed to stand at least $10 \mathrm{~min}$ for precipitation and transferred into the Eppendorf tubes for centrifugation. Centrifugation was done at 1,000 rpm for $5 \mathrm{~min}$. Supernatants were filtered and centrifugation was repeated until clear solution was obtained. Filtrate was stored at low temperature of $-76^{\circ} \mathrm{C}$ till analysis. Electrochemical detection of concentrations of noradrenaline, dopamine, 5-hydroxytryptamine and their metabolites dioxyphenylacetic acid (DOPAC), homovanillic acid (HVA), 5-hydroxyindoleacetic acid (5-HIAA) was done at 0.8 volt operating potential using Shimadzu $\mathrm{L}$ -EC 6A detector of high performance liquid chromatography with electrochemical detection (HPLC-EC) (Haleem et al., 2002; Tahira et al., 2006).

\section{Statistical analysis}

Data expressed are mean \pm standard error of mean (SEM). Data were analyzed by one-way ANOVA followed by Newman-Keuls Post hoc test. All statistical analyses were performed by using Graph Pad Prism version 5.00 for Windows, Graph Pad Software, San Diego, CA, USA. Statistical significance was accepted at a probability level of 0.05 or less.

\section{Results}

\section{Forced swimming test}

In forced swimming test, Newman-Keuls Post hoc test revealed that administration of $V$. vinifera juice $(4 \mathrm{~mL} /$ $\mathrm{kg}$ and $8 \mathrm{~mL} / \mathrm{kg})$ and fluoxetine $(20 \mathrm{mg} / \mathrm{kg})$ produced a significant decrease in immobility time of both unstressed and immobilization-induced stressed mice when compared with their respective saline-treated control groups (Table I).

\section{Tail suspension test}

In tail suspension test, Newman-Keuls Post hoc test revealed that administration of $V$. vinifera juice $(4 \mathrm{~mL} /$ $\mathrm{kg}$ and $8 \mathrm{~mL} / \mathrm{kg})$ and fluoxetine $(20 \mathrm{mg} / \mathrm{kg})$ produced a significant decrease in immobility time of both unstressed and immobilization-induced stressed mice when compared with their respective saline-treated control groups (Table II).

\section{Home cage test}

In home cage test, Newman-Keuls Post hoc test revealed that administration of $V$. vinifera juice $(4 \mathrm{~mL} / \mathrm{kg}$ and 8 $\mathrm{mL} / \mathrm{kg}$ ) and fluoxetine $(20 \mathrm{mg} / \mathrm{kg})$ did not show any significant difference in locomotor activity of both unstressed and immobilization-induced stressed mice when compared with their respective saline-treated control group (Table III).

\section{Neurotransmitter analyses}

In neurotransmitter analyses, Newman-Keuls Post hoc test revealed that administration of $V$. vinifera juice (4 $\mathrm{mL} / \mathrm{kg}$ and $8 \mathrm{~mL} / \mathrm{kg}$ ) produced a significant increase in levels of noradrenaline and serotonin when compared with their respective saline-treated control groups. However, the levels of dopamine were significantly decreased (Table IV).

\section{Discussion}

The current study demonstrated that $V$. vinifera juice (4 $\mathrm{mL} / \mathrm{kg}$ and $8 \mathrm{~mL} / \mathrm{kg}$, p.o) possesses antidepressant-like activity in unstressed and immobilization-induced stressed mice. Forced swimming test and tail suspension test were utilized for assessment of antidepressantlike activity. These models are broadly utilized in rodents to anticipate antidepressant-like potential by evaluating the reduction in immobility time (Rodrigues et al., 2002; Suzuki et al., 2001). The behavioral parameter measured in both tests is called immobility, resembling a behavioral condition of hopelessness, as evidenced in human depression (Steru et al., 1985). In forced swimming test, mice are compelled to swim in a 
Table I

Effect of Vitis vinifera juice on immobility time of mice in forced swimming test

\begin{tabular}{|lcrrr|}
\hline Treatment & $\begin{array}{c}\text { Immobility time on } \\
\text { day } 7\end{array}$ & $\begin{array}{c}\text { Immobility time on } \\
\text { day } 15\end{array}$ & $\begin{array}{c}\text { Immobility time on } \\
\text { day } 30\end{array}$ & $\begin{array}{c}\text { Immobility time on } \\
\text { day } 60\end{array}$ \\
\hline Saline $(8 \mathrm{~mL} / \mathrm{kg})$ & $122.2 \pm 6.6$ & $122.9 \pm 5.4$ & $122.8 \pm 5.0$ & $122.2 \pm 5.83$ \\
Stress + Saline $(8 \mathrm{~mL} / \mathrm{kg})$ & $161.6 \pm 6.6^{\mathrm{b}}$ & $163.6 \pm 4.8^{\mathrm{b}}$ & $162.8 \pm 13.6^{\mathrm{b}}$ & $162.6 \pm 15.0^{\mathrm{b}}$ \\
V. vinifera juice $(4 \mathrm{~mL} / \mathrm{kg})$ & $114.8 \pm 5.4^{\mathrm{a}}$ & $108.6 \pm 4.2^{\mathrm{b}}$ & $80.3 \pm 4.5^{\mathrm{c}}$ & $75.6 \pm 4.4^{\mathrm{c}}$ \\
V. vinifera juice $(8 \mathrm{~mL} / \mathrm{kg})$ & $94.0 \pm 3.8^{\mathrm{c}}$ & $85.3 \pm 4.9^{\mathrm{c}}$ & $75.6 \pm 4.7^{\mathrm{c}}$ & $71.5 \pm 4.0^{\mathrm{c}}$ \\
Fluoxetine $(20 \mathrm{mg} / \mathrm{kg})$ & $101.5 \pm 3.8^{\mathrm{c}}$ & $60.7 \pm 4.6^{\mathrm{c}}$ & $50.6 \pm 2.8^{\mathrm{c}}$ & $48.6 \pm 3.4^{\mathrm{c}}$ \\
Stress + V. vinifera juice $(4 \mathrm{~mL} / \mathrm{kg})$ & $154.8 \pm 13.0$ & $140.2 \pm 12.7^{\mathrm{d}}$ & $112.3 \pm 13.3^{\mathrm{f}}$ & $105.6 \pm 13.4^{\mathrm{f}}$ \\
Stress + V. vinifera juice $(8 \mathrm{~mL} / \mathrm{kg})$ & $134.0 \pm 14.6^{\mathrm{e}}$ & $121.3 \pm 13.0^{\mathrm{f}}$ & $109.6 \pm 13.0^{\mathrm{f}}$ & $101.5 \pm 13.9^{\mathrm{f}}$ \\
Stress + Fluoxetine $(20 \mathrm{mg} / \mathrm{kg})$ & $136.3 \pm 13.4^{\mathrm{e}}$ & $90.7 \pm 12.9^{\mathrm{f}}$ & $80.6 \pm 14.1^{\mathrm{f}}$ & $78.6 \pm 13.3^{\mathrm{f}}$ \\
\hline
\end{tabular}

Number of animals $=10$; The values are mean \pm S.E.M.; ${ }^{a}<0.05 ;{ }^{b} p<0.01 ; \mathrm{c}<<0.001$ when compared with saline-treated unstressed mice; ${ }^{\mathrm{p}} \mathrm{p}<0.05$; e $\mathrm{p}<0.01 ; \mathrm{f} \mathrm{p}<0.001$ when compared with saline-treated stressed mice (One-way ANOVA followed by Newman-Keuls Post hoc test)

\begin{tabular}{|lcccc|}
\hline \multicolumn{5}{c|}{ Table II } \\
\hline \multicolumn{4}{|c|}{ Effect of Vitis vinifera juice on immobility time of mice in tail suspension test } \\
\hline & $\begin{array}{c}\text { Immobility time on } \\
\text { day } 7\end{array}$ & $\begin{array}{c}\text { Immobility time on } \\
\text { Treatment }\end{array}$ & $\begin{array}{c}\text { Immobility time on } \\
\text { day } 30\end{array}$ & $\begin{array}{c}\text { Immobility time on } \\
\text { day } 60\end{array}$ \\
\hline Saline $(8 \mathrm{~mL} / \mathrm{kg})$ & $223.4 \pm 7.0$ & $223.8 \pm 6.7$ & $225.9 \pm 6.0$ & $222.6 \pm 7.5$ \\
Stress + Saline $(8 \mathrm{~mL} / \mathrm{kg})$ & $255.0 \pm 10.9^{\mathrm{a}}$ & $253.8 \pm 12.1^{\mathrm{a}}$ & $255.8 \pm 11.8^{\mathrm{a}}$ & $248.7 \pm 12.0^{\mathrm{a}}$ \\
V. vinifera juice $(4 \mathrm{~mL} / \mathrm{kg})$ & $203.3 \pm 7.8^{\mathrm{b}}$ & $202.2 \pm 12.1^{\mathrm{b}}$ & $194.9 \pm 10.6^{\mathrm{c}}$ & $183.0 \pm 5.6^{\mathrm{c}}$ \\
V. vinifera juice $(8 \mathrm{~mL} / \mathrm{kg})$ & $195.2 \pm 8.9^{\mathrm{c}}$ & $180.0 \pm 8.5^{\mathrm{c}}$ & $171.8 \pm 6.4^{\mathrm{c}}$ & $168.1 \pm 7.2^{\mathrm{c}}$ \\
Fluoxetine $(20 \mathrm{mg} / \mathrm{kg})$ & $162.0 \pm 10.0^{\mathrm{c}}$ & $155.7 \pm 10.4^{\mathrm{c}}$ & $150.6 \pm 10.7^{\mathrm{c}}$ & $143.0 \pm 10.2^{\mathrm{c}}$ \\
Stress + V. vinifera juice $(4 \mathrm{~mL} / \mathrm{kg})$ & $232.6 \pm 14.7$ & $229.2 \pm 9.4$ & $220.9 \pm 11.6^{\mathrm{e}}$ & $205.0 \pm 7.6^{\mathrm{f}}$ \\
Stress + V. vinifera juice $(8 \mathrm{~mL} / \mathrm{kg})$ & $219.8 \pm 13.0^{\mathrm{d}}$ & $201.1 \pm 17.3^{\mathrm{e}}$ & $190.3 \pm 14.4^{\mathrm{f}}$ & $188.1 \pm 14.7^{\mathrm{f}}$ \\
Stress + Fluoxetine $(20 \mathrm{mg} / \mathrm{kg})$ & $172.0 \pm 8.4^{\mathrm{f}}$ & $165.7 \pm 9.2^{\mathrm{f}}$ & $160.6 \pm 10.1^{\mathrm{f}}$ & $151.0 \pm 9.5^{\mathrm{f}}$ \\
\hline
\end{tabular}

Number of animals $=10$; The values are mean \pm S.E.M.; a $<0.05, b p<0.01, c p<0.001$ when compared with saline-treated unstressed mice; ${ }^{\mathrm{d} p}<0.05$, ${ }^{e} \mathrm{p}<0.01, \mathrm{f} \mathrm{p}<0.001$ when compared with saline-treated stressed mice (One-way ANOVA followed by Newman-Keuls Post hoc test)

Table III

\begin{tabular}{|lccccc|}
\hline \multicolumn{5}{c}{ Effect of Vitis vinifera juice on number of cage crossings in home cage test } \\
\hline Treatment & $\begin{array}{c}\text { Cage crossings on } \\
\text { day } 7\end{array}$ & $\begin{array}{c}\text { Cage crossings on } \\
\text { day } 15\end{array}$ & $\begin{array}{c}\text { Cage crossings on } \\
\text { day } 30\end{array}$ & $\begin{array}{c}\text { Cage crossings on } \\
\text { day } 60\end{array}$ \\
\hline Saline $(8 \mathrm{~mL} / \mathrm{kg})$ & $286.5 \pm 17.9$ & $319.2 \pm 13.9$ & $313.5 \pm 18.8$ & $313.2 \pm 14.8$ \\
Stress + Saline $(8 \mathrm{~mL} / \mathrm{kg})$ & $251.5 \pm 16.7$ & $245.7 \pm 7.0 \mathrm{~b}$ & $260.5 \pm 6.7 \mathrm{a}$ & $260.3 \pm 7.1$ a \\
V. vinifera juice $(4 \mathrm{~mL} / \mathrm{kg})$ & $285.4 \pm 10.7$ & $309.1 \pm 14.0$ & $293.5 \pm 22.9$ & $303.2 \pm 14.8$ \\
V. vinifera juice $(8 \mathrm{~mL} / \mathrm{kg})$ & $276.5 \pm 11.7$ & $304.2 \pm 12.9$ & $287.0 \pm 21.6$ & $288.2 \pm 10.7$ \\
Fluoxetine $(20 \mathrm{mg} / \mathrm{kg})$ & $281.0 \pm 12.9$ & $303.2 \pm 12.8$ & $287.5 \pm 24.5$ & $292.2 \pm 13.5$ \\
Stress + V. vinifera juice $(4 \mathrm{~mL} / \mathrm{kg})$ & $247.5 \pm 8.4$ & $243.2 \pm 16.5$ & $258.5 \pm 18.0$ & $257.2 \pm 14.0$ \\
Stress + V. vinifera juice $(8 \mathrm{~mL} / \mathrm{kg})$ & $252.5 \pm 10.1$ & $247.7 \pm 13.0$ & $257.0 \pm 17.1$ & $258.2 \pm 9.0$ \\
Stress + Fluoxetine $(20 \mathrm{mg} / \mathrm{kg})$ & $245.9 \pm 9.8$ & $243.2 \pm 13.7$ & $243.0 \pm 14.3$ & $258.7 \pm 8.5$ \\
\hline
\end{tabular}

Number of animals $=10$; The values are mean \pm S.E.M.; ap $<0.05,{ }^{b} p<0.01$ when compared with saline-treated unstressed mice (One-way ANOVA followed by Newman-Keuls Post hoc test) 


\begin{tabular}{|lccc|}
\hline \multicolumn{4}{|c|}{ Table IV } \\
\hline & Effect of Vitis vinifera juice on neurotransmitter levels in mice brain & \\
\hline Treatment & $\begin{array}{c}\text { Noradrenaline } \\
(\mathrm{ng} / \mathrm{g})\end{array}$ & $\begin{array}{c}\text { Dopamine } \\
(\mathrm{ng} / \mathrm{g})\end{array}$ & $5-\mathrm{HT}$ \\
& $21.5 \pm 0.7$ & $19.4 \pm 0.9$ & $35.6 \pm 1.5$ \\
\hline Control $($ saline $8 \mathrm{~mL} / \mathrm{kg})$ & $27.7 \pm 0.8^{\mathrm{b}}$ & $15.6 \pm 0.3^{\mathrm{a}}$ & $45.2 \pm 3.7^{\mathrm{a}}$ \\
Vitis vinifera $(4 \mathrm{~mL} / \mathrm{kg})$ & $42.8 \pm 1.2^{\mathrm{b}}$ & $7.5 \pm 0.3^{\mathrm{b}}$ & $72.2 \pm 2.0^{\mathrm{b}}$ \\
Vitis vinifera $(8 \mathrm{~mL} / \mathrm{kg})$ & & & \\
\hline
\end{tabular}

Number of animals $=10$; The values are mean \pm S.E.M.; ${ }^{a} \mathrm{p}<0.05 ;{ }^{b}<<0.001$ when compared with saline-treated control mice (One-way ANOVA followed by Newman-Keuls Post hoc test)

limited space from which they can't get away, and are actuated to a specific behavior of immobility. This behavior shows a condition of despair which can be diminished by antidepressant drugs used to treat human depression. Like forced swimming test, The tail suspension test also instigates a condition of immobility in mice. This immobility is referred as behavioral despair in animals, which is said to reproduce a state that resembles human depression (Borsini and Meli, 1988; Steru et al., 1985).

Antidepressants, for example, imipramine have been demonstrated to influence locomotor activity, which could prompt false-positive results (Borsini and Meli, 1988). We utilized home cage activity to ensure the antidepressant-like effect of $V$. vinifera juice. Our results of decrease in immobility time suggest that $V$. vinifera juice has antidepressant-like activity without influencing locomotor activity.

The amine hypothesis of depression proposes that diminished levels of serotonin and/or noradrenaline in the brain precipitate depression, and medications that increase the amine neurotransmitters alleviate depression (Belmaker and Agam, 2008; Krishnan and Nestler, 2008). Almost all antidepressant drugs produce their actions by acting on one or more of the following mechanisms: Inhibition of 5-HT reuptake or noradrenaline (and dopamine), inhibition of monoamine oxidase or antagonism of inhibitory preganglionic noradrenaline or 5-HT receptors. These mechanisms result in an increased neurotransmission of noradrenaline and/or 5-HT. There is sufficient evidence for the involvement of noradrenaline in depression, and late studies on neuronal pathways and manifestations highlight the particular part of noradrenaline in this disease (Chantal and Mike, 2011). A number of studies propose that noradrenaline is a neurotransmitter of major importance in the pathophysiology and management of depression and related conditions (Stahl, 2008). The results of our study show that $V$. vinifera juice has significantly increased the levels of noradrenaline in the brain tissue. This effect of the juice might have been responsible for relieving the depression-like behavior in mice. The unquestioned antidepressant effect of noradrenaline-selective tricyclic antidepressant drugs such as nortriptyline and desipramine recommends a noteworthy inclusion of noradrenaline neurotransmission in depression, despite the fact that these drugs or their metabolites likewise have some activity on the 5 -HT system. Studies show that there is a decrease in 5HT and/or 5-HIAA levels in the brain patients of depression (Mann et al., 1989).

5-HT agonists have anxiolytic and antidepressant effects (Saima et al., 2006). Selective serotonin reuptake inhibitors are viewed as first-line pharmacotherapy for major depressive disorder (MDD) and other mood disorders (Donald, 2007). On the other hand, a particular arrangement of indications identified with diminished positive affect respond poorly to serotonergic antidepressants (Chantal and Mike, 2011).

Therapeutic agents which particularly enhance noradrenaline activity are powerful antidepressants, and there is proof that those acting at the same time on 5-HT and noradrenaline neurotransmission may have antidepressant activity better than selective serotonin reuptake inhibitors (Papakostas et al., 2007) V. vinifera juice has dual action on amine neurotransmitters, that is mean to say that it increases both noradrenaline and 5HT levels in brain tissue, so it can be newer dual-acting antidepressant agent with superior efficacy and broader pharmacologic spectrum.

\section{Conclusion}

This study suggests the possible use of $V$. vinifera juice towards a wide range of depressive disorders and proposed the antidepressant-like activity of the $V$. vinifera juice.

\section{Conflict of Interest}

The authors declare that there is no conflict of interests regarding the publication of this paper.

\section{Ethical Issue}

The specifications given in Helsinki Resolution 1964 were followed during animal handling. This research was approved by The Board of Advanced Studies and 
Research, University of Karachi vide BASR resol. No. 16 dated 26-08-2013.

\section{References}

Ali K, Maltese F, Choi Y, Verpoorte R. Metabolic constituents of grapevine and grape-derived products. Phytochem Rev. 2009; 9: 357-78.

Belmaker R, Agam G. Major depressive disorder. N Engl J Med. 2008; 358: 55-68.

Borsini F, Meli A. Is the forced swimming test a suitable model for revealing antidepressant activity? Psychopharmacol 1988; 94: 147-60.

Bowers J. Historical genetics: The parentage of chardonnay, gamay, and other wine grapes of Northeastern France. Science 1999; 285: 1562-65.

Chantal M, Mike B. The importance of norepinephrine in depression. Neuropsychiatr Dis Treat. 2011; 7: 9-13.

Cheong H, Ryu S, Kim K. Anti-allergic action of resveratrol and related hydroxystilbenes. Planta Med. 1999; 65: 266-68.

Chuang C, Shi Y, You H, Lo Y, Pan T. Antidepressant effect of GABA-rich Monascus- fermented product on forced swimming rat model. J Agric Food Chem. 2011; 59: 3027-34.

Dang H, Chen Y, Liu X, Wang Q, Wang L, Jia W, Wang Y. Antidepressant effects of ginseng total saponins in the forced swimming test and chronic mild stress models of depression. Prog Neuro-Psychopharmacol Biol Psychiatry. 2009; 33: 1417 -24 .

Dhingra D, Chhillar R. Antidepressant-like activity of ellagic acid in unstressed and acute immobilization-induced stressed mice. Pharmacol Reports. 2012; 64: 796-807.

Donald SR. The role of dopamine and norepinephrine in depression. Prim Psychiatry. 2007; 14: 21-23.

Fava M. Diagnosis and definition of treatment-resistant depression. Biol Psychiatry. 2003; 53: 649-59.

Frankel E. Inhibition of human LDL oxidation by resveratrol. Lancet. 1993; 341: 1103-04.

Freitas A, Budni J, Lobato K, Binfaré R, Machado D, Jacinto J, Veronoze PO, Pizzolatti MJ, Rodrigues AL. Antidepressantlike action of the ethanolic extract from Tabebuia avellanedae in mice: Evidence for the involvement of the monoaminergic system. Prog Neuropsychopharmacol Biol Psychiatry. 2010; 34: 335-43.

Haleem DJ, Saify ZS, Sonia S, Farhat B, Haleem MA. Pre and postsynaptic responses to 1-(1-naphthylpiperazine) following adaptation to stress in rats. Prog Neuropsychopharmacol Biol Psych. 2002; 26: 149-56.

Ikram H, Ahmad S, Haleem DJ. Effects of apomorphine on locomotive activity and monoamine metabolism: A dose related study. Pak J Pharm Sci. 2011; 24: 315-21.

Krishnan V, Nestler EJ. The molecular neurobiology of depression. Nature 2008; 455: 894-902.

Liao J, Tsai J, Liu C, Huang H, Wu L, Peng W. Antidepressantlike activity of turmerone in behavioral despair tests in mice.
BMC Complement Altern Med. 2013; 13: 299.

Mann JJ, Arango V, Marzuk PM, Theccanat S, Reis DJ. Evidence for the 5-HT hypothesis of suicide: A review of postmortem studies. Br J Psychiatry. 1989; 8: 7-14.

Papakostas GI, Thase ME, Fava M, Nelson JC, Shelton RC. Are antidepressant drugs that combine serotonergic and noradrenergic mechanisms of action more effective than the selective serotonin reuptake inhibitors in treating major depressive disorder? A meta-analysis of studies of newer agents. Biol Psychiatry. 2007; 62: 1217-27.

Porsolt R, Anton G, Blavet N, Jalfre M. Behavioural despair in rats: A new model sensitive to antidepressant treatments. Eur J Pharmacol. 1978; 47: 379-91.

Saima K, Saida H, Shaida PA, Tahira P, Darakhshan JH. Relationship of brain tryptophan and serotonin in improving cognitive performance in rats. Pak J Pharm Sci. 2006; 19: 1115.

Saito M, Hosoyama H, Ariga T, Kataoka S, Yamaji N. Antiulcer activity of grape seed extract and procyanidins. J Agric Food Chem. 1998; 46: 1460-64.

Sheikh N, Ahmad A, Siripurapu K, Kuchibhotla V, Singh S, Palit G. Effect of Bacopa monniera on stress-induced changes in plasma corticosterone and brain monoamines in rats. J Ethnopharmacol. 2007; 111: 671-76.

Stahl SM. Stahl's Essential psychopharmacology: Neuroscientific basis and practical applications. $3^{\text {rd }}$ ed. New York, Cambridge University Press, 2008.

Steru L, Chermat R, Thierry B, Simon P. The tail suspension test: A new method for screening antidepressants in mice. Psychopharmacology 1985; 85: 367-70.

Rodrigues A, da Silva G, Mateussi A, Fernandes E, Miguel O, Yunes R, Calixto J, Santos A. Involvement of monoaminergic system in the antidepressant-like effect of the hydroalcoholic extract of Siphocampylus verticillatus. Life Sci. 2002; 70: 134758.

Suzuki E, Yagi G, Nakaki T, Kanba S, Asai M. Elevated plasma nitrate levels in depressive states. J Affect Disord. 2001; 63: 221-24.

Tahira P, Roomana R, Sadia H, Darakhan JH. Increased serotonergic functions following administration of 1-(1-naphthyl) piperazine in propranolol injected rats. Pak J Pharm Sci. 2006; 19: 190-94.

Xia E, Deng G, Guo Y, Li H. Biological activities of polyphenols from grapes. IJMS. 2010; 11: 622-46.

Yi L, Xu H, Feng J, Zhan X, Zhou L, Cui C. Involvement of monoaminergic systems in the antidepressant-like effect of nobiletin. Physiol Behavior. 2011; 102: 1-6.

Zheng M, Fan Y, Shi D, Liu C. Antidepressant-like effect of flavonoids extracted from Apocynum venetum leaves on brain monoamine levels and dopaminergic system. J Ethnopharmacol. 2013; 147: 108-13.

Author Info
e-mail: Pharmacologist1@yahoo.com: Tel: $+92-3452220192$

